\title{
Implementasi Kebijakan Progran Keluarga Harapan (PKH) di Kelurahan Cigadung Kabupaten Subang
}

\author{
Kusman Yuhana' \\ Fakultas Ilmu Administrasi Universitas Subang \\ kusmanyuhana.jurnal@gmail.com \\ Titin Kartini ${ }^{2}$ \\ Fakultas Ilmu Administrasi Universitas Subang \\ titin.unsub@gmail.com
}

\begin{abstract}
Abstrak
Hasil penelitiannya menunjukan Implementasi PKH di Kelurahan Cigadung Kecamatan Subang belum optimal. Hal ini berarti masih banyak yang harus diperhatikan dan ditingkatkan dalam mekanisme maupun prosedur yang ada, dilihat dari proses kegiatan perrtemuan awal, validasi, pembentukan kelompok, pemuhtahiran data, verifikasi komitmen peserta dan penyaluran bantuan sesuai dengan ketentuan. Kemudian beberapa faktor pendukung dalam implementasi program $\mathrm{PKH}$ dukungan kelembagaan $\mathrm{PKH}$ yang telah berjalan efektif, semangat dan atusias KPM dalam menjalani Program, PKH memiliki kejelasan isi yang memudahkan pendamping dan KPM dalam menjalankan program, Lembaga bayar menyalurkan dana bantuan tepat jumlah dan tepat waktu. Faktor penghambat implementasi PKH di Kelurahan Cigadung meliputi kendala sumber data yang kurang akurat, sering kali terjadi kecemburuan sosial antara KPM dan masyarakat setempat, rendahnya daya tangkap dari KPM berlatar belakang pendidikan (SD/SMP kurang memahami PKH dan dalam penggunaan dana PKH oleh KPM kerap digunakan diluar ketentuan. Untuk jangka panjang belum bisa merubah pola pikir dan perilaku RTSM secara siginifikan.
\end{abstract}

Kata Kunci: Implementasi Kebijakan, Program Keluarga Harapan (PKH)

\begin{abstract}
This research used theory of implementation approach of policy of Daniel Mazmanin and Paul Sabtier. This theory sees the variable in controlling the problem. Variable of ability of policy in structuring the implementation process accurately and variable from outside of policy that influence the implementation process. This research used descriptive methodology with qualitative approach. The data collecting was done by monitoring and interview thoroughly. The result of this research showed that the implementation of family of expectancy program in Cigadung District Subang Regency had many obstructions and had not been done well yet. The socialization had not thoroughly, so that it could not get supports from the stakeholder. There were still many poor
\end{abstract}


families had not got the assistance of this program. The guidance had not done well yet. The use of financial support of this program was out of its function. For long-range, it could not change mindset and attitude of poor family significantly.

Keywords: Policy implementation, Family of Expectancy Program

\section{Pendhauluan}

Kemiskinan merupakan masalah kompleks yang dipengaruhi oleh berbagai faktor, anatara lain, pendapatan, pendidikan, lokasi, gender, dan kondisi lingkungan. Kemiskinan di Indonesia dicirikan oleh banyaknya rumah tangga yang berada disekitar garis kemiskinan. Akibatnya, meski tidak tergolong miskin, mereka rentan terhadap kemiskinan. Kemiskinan adalah kurangnya kesejahteraan. Pendapat konvesional mengaitkan kesejahteraan terutama dengan kepemilikan barang, sehingga masyarakat miskin diartikan sebagai mereka yang tidak memilki pendapatan atau konsumsi yang memadai untuk membuat mereka berada diatas ambang minimal kategori sejahtera. Kemiskinan juga dapat dikaitkan dengan suatu jenis konsumsi tertentu. Sebagai contoh, suatu masyarakat dapat saja dikatakan miskin karena tidak memiliki tempat tinggal, kekurangan pangan, atau memilki kondisi kesehatan yang buruk. . (Khoman Ali,dkk:13) Kemiskinan merupakan persoalan yang multidimensional yang tidak saja melibatkan faktor ekonomi, tetapi juga sosial, budaya dan politik. Seseorang atau keluarga miskin bisa disebabkan oleh beberapa faktor yang saling berkaitan satu sama lain, seperti mengalami kecacatan, memiliki pendidikan rendah, tidak memiliki modal atau keterampilan untuk berusaha, tidak tersediannya lapangan pekerjaan, terkenan pemutusan hubungan kerja (PHK), tidak adanya jaminan sosial(pensiun, kesehatan, kematian), atau hidup dilokasi terpencil dengan sumberdaya alam dan infrasturktur yang terbatas. (Khoman Ali,dkk:13) Berdasarkan Undang-Undang Nomor 40 Tahun 2004 tentang Sistem Jaminan Sosial Nasional, Undang-Undang Nomor 11 Tahun 2010 Tentang Kesejahteraan Sosial, dan UndangUndang Nomor 13 Tahun 2011 Tentang Penanganan Fakir Miskin, serta aturan lainnya dalam mendukungya. Untuk meminimalisir permasalahan kesejahteraan sosial, khususnya kemiskinan maka, Pemerintah Indonesia memiliki berbagai program penanggulangan berbasis bantuan sosial, program penanggulangan kemiskinan yang berbasis pemberdayaan masyarakat serta program penanggulangan kemiskinan yang berbasis pemberdayaan usaha kecil. Salah satu program berbasis bantuan sosial dari dari pemerintah yaitu Program Keluarga Harapan (PKH). Pemerintahan Indonesia melalui Kementrian Sosial mengeluarkan Program Keluarga Harapan (PKH). Program ini dilaksanakan oleh Dinas Sosial yang merupakan salah satu instansi pemerintah yang bergerak di bidang sosial. Program ini berupaya untuk mengembangkan sistem perlindungan sosial terhadap warga miskin di Indonesia.

Berdasarkan Peraturan Bupati Subang Nomor : 63 Tahun 2016 Tentang Tugas Pokok, Fungsi Dan Tata Kerja Dinas Sosial Kabupaten Subang Bidang Perlindungan dan Jaminan Sosial Pasal 9. Bidang Perlindungan dan Jaminan Sosial mempunyai fungsi : (a) Penyusunan rencana kegiatan Seksi Penyelenggaraan Jaminan Sosial; (b) 
Pelaksanaan penyusunan bahan kebijakan teknis dan fasilitas Penyelenggaraan Jaminan Sosial; (c) Pelaksanaan penyusunan bahan fasilitas Penyelenggaraan Jaminan Sosial; (d) Pelaksanaan fasilitas Penyelenggara Jaminan Sosial; (e) Pelaksanaan Pembinaan Program Keluarga Harapan dan Program Jaminan Sosial lainnya; (f) Menyelenggarakan koordinasi pada Penyelenggaraan Jaminan Sosial; (g) Pengolaan Data dan Informasi Seksi Penyelenggaraan Jaminan Sosial; (h) Penyusunan Laporan hasil kegiatan pada Seksi Penyelenggaraan Sosial.

Program unggulan yang di klaim pemerintah, salah satunya adalah PKH (Program Keluarga Harapan). PKH merupakan salah satu program Conditional Cash Transfer (CCT) yang juga dikenal di dunia dalam menanggulangi kemiskinan yang kronis, sebagai bentuk penanggulangan sosial. Program ini memberikan bantuan dana kepada RTSM (Rumah Tangga Sangat Miskin). Sebagai upaya percepatan penanggulangan kemiskinan, sejak tahun 2007 Pemerintah Indonesia telah mengklaim melaksanakan Program Bantuan Tunai Bersyarat (BTB) yang dikenal dengan nama Program Keluarga Harapan (PKH) tersebut. Bantuan dana PKH yang diberikan berorientasi kepada kemapanan untuk memenuhi kewajibannya dibidang pendidikan dan kesehatan. Tidak semua RTSM bisa menjadi peserta PKH, hanya keluarga yang mempunyai ibu hamil dan/atau terdapat anak yang berusia 0-15 tahun yang dapat mengaksesnya. Program perlindungan sosial ini bertujuan meningkatkan kualitas hidup Keluarga Sangat Miskin (KSM) dengan syarat mengakses layanan kesehatan dan pendidikan tertentu yang telah ditetapkan bagi Keluarga Sangat Miskin (KSM). Dengan pemberian akses ini, diharapkan terjadi perubahan perilaku yang mendukung tercapainya kesejahteraan sosial. (Pedoman PKH Dinas Sosial)

Dalam jangka pendek dana bantuan PKH bertujuan untuk mengurangi beban pengeluaran rumah tangga (dampak konsumsi langsung), dan dalam jangka panjang merupakan investasi generasi masa depan yang lebih baik melalui peningkatan kesehatan dan pendidikan (dampak pengembangan modal manusia). Artinya, PKH diharapkan oleh pemerintah sebagai program yang mampu memutus rantai kemiskinan antar generasi. Sementara secara khusus, tujuan PKH adalah: (1) meningkatkan akses dan kualitas pelayanan pendidikan dan kesehatan bagi peserta PKH; (2) meningkatkan taraf pendidikan peserta; (3) meningkatkan status kesehatan dan gizi ibu hamil (bumil), ibu nifas, bawah lima tahun (balita) dan anak prasekolah anggota Keluarga Sangat Miskin (KSM); (4) meningkatkan kondisi sosial ekonomi para peserta PKH.

Tujuan utama PKH kesehatan adalah meningkatkan status kesehatan ibu dan anak di Indonesia, khususnya bagi kelompok masyarakat sangat miskin, melalui pemberian insentif untuk melakukan kunjungan kesehatan yang bersifat preventif (pencegahan, dan bukan pengobatan). Seluruh peserta PKH merupakan penerima jasa kesehatan garis yang disediakan oleh program Askeskin dan program lain yang diperuntukkan bagi orang tidak mampu. Kartu PKH bisa digunakan sebagai alat identitas untuk memperoleh pelayanan tersebut. Komponen pendidikan dalam PKH dikembangkan untuk meningkatkan angka partisipasi pendidikan dasar wajib 9 tahun serta upaya mengurangi angka pekerja anak pada keluarga yang sangat miskin. Anak penerima PKH Pendidikan yang berusia 7-18 tahun dan belum menyelesaikan program pendidikan dasar 9 tahun harus mendaftarkan diri di sekolah formal atau non formal serta hadir sekurang-kurangnya $85 \%$ waktu tatap muka. Setiap anak peserta PKH berhak menerima bantuan selain $\mathrm{PKH}$, baik itu program nasional maupun lokal. 
Bantuan PKH bukanlah pengganti program-program lainnya karena tidak cukup membantu pengeluaran lainnya seperti seragam, buku dan sebagainya. PKH merupakan bantuan agar orang tua dapat melanjutkan pendidikan keseluruh dalam rangka untuk melanjutkan pendidikan anak. (Pedoman PKH Dinas Sosial)

Alasan melakukan penelitian di Kelurahan Cigadung yaitu karena Kelurahan Cigadung merupakan salah satu kelurahan dari 8 (delapan) Kelurahan yang ada di Kecamatan Subang yang melaksanakan Program Keluarga Harapan dan dapat dikatakan masih belum optimal. Implementasi kebijakan Program Keluarga Harapan di Kelurahan Cigadung tidak terlepas dari hambatan. Adapun persoalan dalam implementasi kebijakan Program Keluarga Harapan di Kelurahan Cigadung yakni mengenai keterbatasan kuota bantuan PKH. Dan masalah lain dalam implementasi kebijakan Program Keluarga Harapan yaitu keurang kompeten nya pendamping menangani 798 kpm yang mana Kelurahan Cigadung terdiri dari 28 RW.

Aktor penentu dalam Program Keluarga Harapan yang bertanggung jawab di pemerintahan daerah Kabupaten Subang Provinsi Jawa Barat dalam Bidang Perlindungan dan Jaminan Sosial, meliputi Seksi Perlindungan Sosial Korban Tindak Kekerasan dan Pekerja Migran, Seksi Perlindungan Sosial Korban Bencana dan Seksi Penyelenggara Jaminan Sosial. Adapun yang melaksanakan kegiatan dilapangan yaitu Unit Pelaksana Program Keluarga Harapan (UPPKH) dan Pendampingan. Kelurahan Cigadung merupakan salah satu kelurahan yang mempunyai jumlah keluarga miskin yang cukup banyak. Dengan jumlah penduduk \pm 25.000 jiwa, dengan jumlah peserta Program Keluarga Harapan sebanyak 798 KPM. Dengan adanya Program Keluarga Harapan di Kelurahan Cigadung diharapkan dapat mengurangi kemiskinan dan meningkatkan kualitas sumber daya manusia yaitu pendidikan, kesehatan dan kesejahteraan sosial pada kelompok masyarakat miskin. Tetapi yang menjadi kendala adalah data penerima PKH yang masih menggunakan data lama, data yang tidak valid dan update menimbulkan banyak masyarakat yang merasa tidak adil. Seperti masih ditemukan warga yang sesungguhnya sudah tergolong mampu, tapi dalam data bantuan sosial masih belum dicoret.

Berdasarkan hasil penelitian penulis diketahui bahwa, implementasi kebijakan PKH di Kelurahan Cigadung Kecamatan Subang belum berjalan dengan baik, terlihat dari persoalan, sumberdaya manusia dan kepentingan kelompok sasaran atau target groups masih lemah. Selain itu persoalan lain dalam sebuah program kebijakan adalah berkaitan dengan pendampingan yang tidak maksimal. Kepentingan kelompok sasaran perlu diperhatikan, ini adalah salah satu variabel yang harus diperhatikan. Dengan mengetahui kepentingan kelompok sasaran maka akan mempermudah pencapaian efesiensi dan efektivitas dari setiap program yang dilaksanakan. Melihat dari tujuan PKH, seharusnya keluarga miskin yang berada di Kabupaten Subang berkurang, namun dalam kenyataannya tidaklah demikian. Masyarakat miskin tetap bahkan bertambah dan akses pendidikan untuk keluarga miskin dirasa sangat kurang. Peserta penerima bantuan yang termasuk sebagian keluarga yang memiliki perekonomian yang layak hal ini disebabkan karena adanya hubungan keluarga penerima dengan pendamping. Sehingga yang seharusnya mendapatkan tidak mendapatkan bantuan PKH.

Berdasarkan hasil pengamatan dan penelitian di Kelurahan Cigadung Kecamatan Subang diketahui bahwa implementasi kebijakan Program Keluarga Harapan (PKH) belum optimal. Hal ini dapat dilihat dari indikator-indikator sebagai berikut : 
Keterbatasan kuota penerima bantuan program PKH berbanding dengan kebutuhan. Data Rumah Tangga Sangat Miskin (RTSM) dikelurahan cigadung sebanyak \pm 2.200 jiwa sedangkan yang mendapatkan bantuan program hanya $798 \mathrm{kpm}$. Tidak adanya koordinasi antara pendamping dengan pemerintah setempatan; tidak optimalnya proses pendampingan $\mathrm{PKH}$, dilihat dari hasil penjajagan masalah dari petugas pendamping $\mathrm{PKH}$ yang tidak kompeten mengakibatkan lambatnya memverifikasi data; dan waktu pelaksanaan realisasi penyaluran bantuan Program Keluarga Harapan $(\mathrm{PKH})$ tidak sesuai dengan jadwal pelaksanaan. Jadwal penyaluran bantuan PKH yang semestinya dilakukan dilakukan setiap 3 bulan sekali, tetapi dalam realisasinya ada yang dilaksanakan 4 bulan sekali. (Rapat Koordinasi.

\section{Kerangka Teori}

\section{a. Kosem Implementasi Kebijakan Publik}

Implementasi adalah suatu tindakan atau pelaksanaan dari sebuah rencana yang sudah disusun secara matang dan terperinci. Kamus Besar Bahasa Indonesia menyatakan implementasi adalah pelaksanaan; penerapan. Pengertian implementasi menurut beberapa sumber juga menyatakan hal yang sama. Nurdin Usman (2002:170) menjelaskan bahwa implementasi berhubungan pada sebuah aktivitas, aksi, tindakan atau adanya mekanisme suatu sistem, yang bukan sekedar aktivitas tetapi suatu kegiatan yang terencana dan untuk mencapai tujuan kegiatan. Implementasi menurut (Guntur Setiawan, 2014: 39) adalah perluasan aktivitas yang saling menyesuaikan proses interaksi antara tujuan dan tindakan untuk mencapainya serta memerlukan jaringan pelaksana dan birokrasi yang efektif. Sementara menurut Susilo, implementasi merupakan suatu tindakan praktis sehingga memberikan dampak baik berupa perubahan pengetahuan, keterampilan maupun nilai dan sikap. Secara lebih lengkap, implementasi menurut (Joko widodo, 2010:88) merupakan suatu proses yang melibatkan sejumlah sumber yang termasuk manusia, dana dan kemampuan organisasional yang dilakukan oleh pemerintah maupun swasta (individu maupun kelompok). Proses tersebut dilakukan untuk mencapai tujuan yang telah ditetapkan sebelumnya oleh pembuat kebijakan.

Dari beberapa pengertian implementasi di atas memperlihatkan bahwa implementasi bermuara kepada terlaksananya suatu kegiatan sesuai dengan tujuan yang ingin dicapai. Sehingga peneliti menyandarkan pengertian implementasi sebagai suatu kegiatan yang terencana dan sistematis yang melibatkan beberapa sumber-sumber potensial serta dilakukan secara sungguh-sungguh untuk mencapai tujuan kegiatan. Pengertian implementasi di atas apabila dikaitkan dengan kebijakan adalah bahwa sebenarnya kebijakan itu hanya dirumuskan lalu dibuat dalam suatu bentuk positif seperti undang-undang dan kemudian didiamkan dan tidak dilaksanakan atau diimplementasikan, tetapi sebuah kebijakan harus dilaksanakan atau diimplementasikan agar mempunyai dampak atau tujuan yang diinginkan. Implementasi kebijakan adalah hal yang paling berat, karena disini masalah-masalah yang kadang tidak dijumpai didalam konsep, muncul dilapangan. Selain itu, ancaman utama adalah konsistensi implementasi. Dibawah ini akan diuraikan beberapa pendapat para ahli mengenai pengertian implementasi kebijakan publik, seperti yang Daniel Mazmanian dan Paul Sabatier 
sebagaimana dikutip Agustino (2008:139) mendifinisikan implementasi kebijakan sebagai: "Pelaksanaan keputusan kebijaksanaan dasar, biasanya dalam bentuk undang-undang, namun dapat pula berbentuk perintah-perintah atau keputusankeputusan eksekutif yang penting atau keputusan badan peradilan. Lazimnya keptusan tersebut mengindentifikasikan masalah yang ingin diatasi, menyebutnya secara tegas tujuan atau sasaran yang ingin dicapai, dan berbagai cara untuk menstrukturkan atau mengatur proses implementasinya." Sedangkan Van Meter dan Van Horn (dalam Anggara,2014:229), mendifinisikan Implementasi kebijakan, sebagai: "Tindakan-tindakan yang dilakukan baik oleh individu-individu atau pejabat-pejabat atau sekelompok-kelompok pemerintah atau swasta yang diarahkan pada tercapainya tujuan-tujuan yang telah digariskan dalam keputusan kebijaksanaan. Selain itu, Menurut George Edwards (Budi Winarno: 177), "Implementasi kebijakan adalah salah satu tahap kebijakan publik, anatara pembentukan kebijakan dan konsekuensi-konsekuensi kebijakan bagi masyarakat yang dipengaruhinya. Jika suatu kebijakan tidak tepat atau tidak dapat mengurangi masalah yang merupakan sasaran dari kebijakan, maka kebijakan itu mungkin akan mengalami kegagalan sekalipun kebijakan itu diimplementasikan dengan sangat baik." Rifley dan Franklin (1982) berpendapat bahwa implementasi adalah apa yang terjadi setelah undang-undang ditetapkan yang memberikan otoritas program, kebijakan, keuntungan (benefit), atau suatu jenis keluaran yang nyata. Sementara itu menurut " Grindle (1980) ( Budiman Rusli:97) juga memberikan pandangannya tentang implementasi dengan mengatakan bahwa secara umum, tugas implementasi adalah membentuk suatu kaitan yang memudahkan tujuan-tujuan kebijakan bisa direalisasikan sebagai dampak dari suatu kegiatan pemerintah". Dari definisi implementasi yang dipaparkan oleh tokoh diatas, maka implementasi kebijakan dapat diartikan sebagai pelaksanaan dari proses perencanaan yang telah dilakukan sebelumnya dan tetap berpegangan terhadap tujuan yang ingin dicapai.

\section{b. Faktor-faktor yang Mempengaruhi Implementasi Kebijakan}

Menurut Daniel Mazmanian dan Paul Sabatier (1983) (dalam Buku Anggara:257) yang memperkenalkan model implementasi kebijakan publik. Model yang ditawarkan oleh kedua tokoh tersebut mengklasifikasikan proses implementasi kebijakan kedalam tiga variabel. Dimana variabel-variabel tersebut adalah sebagai berikut:

1) Mudah atau tidaknya masalah yang digarap

a. Kesukaran Teknis

Tercapai atau tidaknya tujuan suatu kebijakan akan tergantung pada sejumlah persyaratan teknik, termasuk diantaranya adalah kemampuan untuk mengembangkan indikator-indikator pengukur prestasi kerja yang tidak terlalu mahal serta pemahaman mengenai prinsip-prinsip hubungan kasual yang mempengaruhi masalah.

b. Keberagaman perilaku yang diatur

Semakin beragamnya perilaku yang diatur, maka asumsinya semakin beragam pelayanan yang diberikan, sehingga semakin sulit untuk membuat peraturan yang tegas dan jelas.

c. Tingkat dan ruang lingkup perubahan yang dikehendaki 
Semakin besar jumlah perubahan perilaku yang dikehendaki oleh kebijakan, maka semakin sukar para pelaksana memperoleh hasil yang berhasil.

2) Kemampuan kebijakan menstruktur proses implementasi secara tepat

a. Kejelasan dan konsistensi tujuan

Semakin mampu suatu peraturan memberikan petunjuk-petunjuk yang cermat dan disusun secara jelas skal prioritas kepentingan para pejabat pelaksana dan aktor lainnya, maka semakin besar pula bahwa output kebijakan dari badan-badan pelaksana akan sejalan dengan petunujuk tersebut.

b. Dipergunakannya teori kausal

Memuat teori kausalitas yang menjelaskan bagaimana kira-kira tujuan usaha pembaharuan yang akan dicapai melalui implementasi kebijakan.

c. Ketepatan alokasi sumberdana

Tersediannya dana pada tingkat batas ambang tertentu sangat diperlukan agar terbuka peluang untuk mencapai tujuab formal.

d. Keterpaduan hierarki antara lembaga pelaksana

Ketika kemampuan untuk menyatu padukan dinas, badan, dan lembaga dilaksanakan, maka koordinasi antar instansi yang bertujuan mempermudah jalannya implementasi kebijakan justru akan membuyarkan tujuan dari kebijakan yang telah ditetapkan.

e. Aturan pelaksana dari lembaga pembuat pelaksana

Selain dapat memberikan kejelasan dan konsistensi tujuan, memperkecil jumlah titik-titik veto dan intensif yang memadai bagi kepatuhan kelompok sasaran, suatu undang-undang harus pula dapat mempengaruhi lebih lanjut proses implementasi kebijakan dengan cara menggariskan secara formal aturan-aturan pembuat keputusan dari badan-badan pelaksana.

f. Perekrutan pejabat pelaksana

Para pejabat pelaksana memiliki kesepakatan yang disyaratkan demi tercapainya tujuan.

g. Keterbukaan terhadap pihak luar

Faktor lain yang juga mempengaruhi implementasi kebijakan adalah sejauh mana peluang-peluang terbuka bagi partisipasi para aktor diluar badan pelaksana dapat mendukung tujuan resmi.

3) Variabel diluar kebijakan yang mempengaruhi proses implementasi

a. Kondisi sosial-ekonomi dan teknologi

Perbedaan waktu dan perbedaan diantara wilayah-wilayah hukum pemerintah dalam kondisi sosial, ekonomi, dan teknologi sangat signifikan berpengaruh terhadap upaya pencapaian tujuan yang digariskan dalam suatu undang-undang. Oleh karena itu eksternal faktor juga menjadi hal penting untuk diperhatikan guna keberhasilan suatu upaya mengimplementasikan kebijakan publik.

b. Dukungan publik

Hakikat perhatian publik yang bersifat sesaat menimbulkan kesukaran tertentu, karena untuk mendorong tingkat keberhasilan suatu implementasi kebijakan sangat dibutuhkan adanya sentuhan dukungan 
dari warga. Karena itu, mekanisme partisipasi publik sangat penting artinya dalam proses pelaksanaan kebijakan publik.

c. Sikap dan sumber-sumber yang dimiliki masyarakat

Perubahan-perubahan yang hendak dicapai oleh suatu kebijakan publik akan sangat berhasil apabila ditingkat masyarakat, warga memiliki sumber-sumber dan sikap-sikap masyarakat yang kondusif terhadap kebijakan yang ditawarkan pada mereka. Ada semacam kearifan lokal yang dimiliki pleh warga yang dapat mempengaruhi keberhasilan atau ketidakberhasilan implementasi kebijakan publik. Dan hal tersebut sangat dipengaruhi oleh sikap dan sumber daya yang dimiliki oleh warga masyarakat.

\section{Metode Penelitian}

Metode penelitian yang digunakan penulis dalam penelitian ini adalah metode deskriptif dengan pendekatan kualitatif. Hal ini sesuai dengan tujuan penelitian yaitu mengetahui implementasi kebijakan Program Keluarga Harapan (PKH) di Kelurahan Cigadung Kecamatan Subang Kabupaten Subang. Dengan demikian penelitian ini menggambarkan fakta-fakta dan menjelaskan objek penelitian serta menggali informasi yang dibutuhkan sesuai fenomena, menarasikan hasil pengolahan data dengan menyajikan informasi dalam bentuk teks tertulis atau bentuk-bentuk gambar mati atau hidup seperti foto dan video. Untuk itu teknik penelitian yang digunakan untuk menggali data adalah observasi atau unit pengamatan, wawancara, studi dokumentasi dan dengan melakukan triangulasi. Maka teknik pengumpulan data bersifat triangulasi, yaitu menggunakan berbagai teknik pengumpulan data secara gabungan atau slimutan. Analisis data yang dilakukan bersifat induktif berdasarkan fakta-fakta yang ditemukan dilapangan dan kemudian dikontruksikan menjadi hipotesis atau teori. Alasan pemilihan metode penelitian kualitatif sesuai dengan tujuan penelitian yang akan dilaksanakan.

Metode penelitian kualitatif sering disebut metode penelitian naturalistik karena penelitiannya dilakukan pada kondisi yang alamiah (natural setting), disebut juga sebagai metode etnographi, karena pada awalnya metode ini lebih banyak digunakan untuk penelitian bidang antropologi budaya, disebut sebagai metode kualitatif, karena data yang terkumpul dan analisisnya lebih bersifat kualitatif. Metode penelitian kualitatif adalah metode penelitian yang berlandaskan pada filsafat postpositivisme yaitu sebagai paradigma interprentif dan konstruktif, yang memandang realitas sosial sebagai sesuatu yang holistik/utuh, kompleks, dinamis, penuh makna dan hubungan gejala bersifat interaktif, digunakan untuk meneliti pada kondisi obyek yang alamiah (sebagai lawannya adalah eksperimen) dimana peneliti adalah sebagai instrumen kunci, analisis data bersifat induktif/kualitatif, dan hasil penelitian kualitatif lebih menekankan makna daripada generalisasi. (Sugiyono 2017:8). Pengguanaan metode deskritif dengan pendekatan kualitatif ini memiliki keunggulan karena masalah yang dikaji tidak sekedar berdasarkan laporan pada suatu kejadian atau fenomena saja melainkanjuga dikomfirmasi dengan sumber-sumber lain yang relevan. Berdasarkan tujuan penelitian kualitatif, maka prosedur sampling yang penting adalah bagaimana menemukan informasi kunci (key informan). Orientasi mengenai informan adalah bukan berapa jumlah masyarakat yang dijadikan informan tetapi apakah data yang terkumpul sudah mencukupi atau belum. 


\section{Penentuan Sumber Data dan Informan}

Jumlah dan unsur narasunber yang dijadikan informan penelitian serta rangka informasi masing-masing informan ditentukan menurut sejumlah kriteria yang dirancang atau disusun sebelum penelitian dilakukan.

Penentuan informan penelitian didasarkan kepada pertimbangan-pertimbangan bahwa mereka merupakan individu-individu yang melihat, merasakan dan mengalami secara langsung maupun tidak langsung kegiatan-kegiatan dalam Implementasi Program Keluarga Harapan (PKH) di Kelurahan Cigadung Kecamatan Subang Kabupaten Subang. Beberapa diantara informan peneliti yang berhubungan dengan Implementasi Program Keluarga Harapan (PKH) di Kelurahan Cigadung Kecamatan Subang Kabupaten Subang adalah sebagai berikut :

1. Kasi Kesejateraan Dinas Sosial Kabupaten Subang, karena Dinas Sosial merupakan salah satu instansi pemerintah yang melaksanakan program PKH di Kabupaten Subang.

2. Perwakilan petugas pendamping PKH kecamatan subang karena mengetahui sumber daya manusia yang mendapatkan bantuan Program Keluarga Harapan.

3. Lurah Cigadung dan staf Kasi Kesejahteraan Sosial Kelurahan Cigadung Subang karena dipandang mengetahui tentang pelaksanaan Program Keluarga Harapan.

4. Masyarakat yang menerima PKH di Kelurahan Cigadung karena masyarakat yang merasakan bagaimana Program Keluarga Harapan (PKH) berjalan dengan baik atau tidak.

\section{Hasil dan Pembahasan}

\section{a. Profil Kelurahan Cigadung}

Letak Kelurahan Cigadung sangat strategis, berada di pusat kota Kabupaten Subang, pada waktu itu Kantor Kelurahan Cigadung berada di Jl. H. Agus Salim Blok Purwasari, kemudian pada tahun 1997 Kantor Kelurahan Cigadung pindah menempati Kantor yang baru beralamat di Jl. O. Djayawisastra Nomor 01 Subang. Jarak Kantor Kelurahan Cigadung dengan Kantor Kecamatan Subang kurang lebih $1 \mathrm{~km}$, sedangkan jarak dengan Kantor Peemerintah daerah kurang lebih 1,5 km. Kelurahan Cigadung dilalui oleh dua jalan raya propinsi yang menghubungkan Kabupaten Subang dengan Kabupaten Purwakarta. Kelurahan Cigadung merupakan salah satu dari 8 (Delapan) Kelurahan yang berada di Kecamatan Subang, terletak di sebelah utara Kelurahan Sukamelang, Sebelah Selatan Kelurahan Pasirkareumbi, sebelah timur Kelurahan Karanganyar dan sebelah barat Kelurahan Dangdeur dengan luas wilayah 335,182 ha, terbagi menjadi 28 Rukun Warga dan 88 Rukun Tetangga, selanjutnya berdasaarkan pemanfaatan ruang dan tanah terbagi ke dalam $60 \%$ pemukiman, 20\% persawahan, $10 \%$ perkebunan dan $10 \%$ dimanfaatkan ke dalam sektor jasa lainnya. Visi : Dari hasil komitmen bersama maka visi Kelurahan Cigadung dapat ditentukan sebagai berikut : "Menjadi Kelurahan yang Mandiri Berlandaskan Semangat Kekeluargaan dan Gotong Royong pada Tahun 2020". Selain menyusun visi juga telah ditetapkan misi-misi yang memuat sesuatu pernyataan yang harus dilaksanakan oleh Kelurahan agar tercapainya visi Kelurahan tersebut diatas. Visi berada di atas visi. Pernyataan visi kemudian dijabarkan ke dalam misi agar dapat di operasionalkan / dikerjakan. Sebagaimana penyusunan visi, misi pun dalam penyusunannya 
menggunakan pendekatan partisipasif dan pertimbangan potensi dan kebutuhan Kelurahan Cigadung, sebagaimana proses yang dilakukan maka misi Kelurahan Cigadung adalah sebagai berikut :

1) Mengembangkan potensi Sumber Daya Manusia dan Sumber Daya Alam sehingga menjadi berdayaguna dan berhasilguna

2) Mengembangkan sistem ekonomi kerakyatan yang menunjang pada upaya peningkatan kesejahteraan keluarga

3) Menciptakan suasana yang Aman, Nyaman, Tertib, Bersih dan Indah di lingkungan Kelurahan Cigadung

4) Meningkatkan kualitas pelayanan masyarakat dengan prinsip pelayanan yang Cepat, Tepat, Mudah dan Murah

5) Menjalin hubungan yang harmonis antara Pemerintah di Tingkat Kabupaten, Kecamatan, Kelurahan, RT/RW dan membangun kemitraan yang berpihak pada kepentingan rakyat bersaama pengusaha/swasta

6) Berinovasi dalam konteks peningkatan kualitas pelaksanaan

7) Pembangunan fisik dan nonfisik, penyelenggaraan pemerintahan, dan pembinaan / pemberdayaan kemasyarakatan

8) Memperkuat Tata Kelola Pemerintahan.

Suatu kebijakan publik tidak terlepas dari tahapan implementasi kebijakan. Tahapan ini merupakan salah satu bagian terpenting dari siklus kebijakan publik pada umumnya. Pengimplementasian kebijakan memberikan makna kebijakan lebih dinamis dan realitis daripada sekedar sebagian sebuah ketetapan yang lebih bersifat statis. Implementasi kebijakan publik yang dimaksud penelitian ini adalah implementasi dari Peraturan Menteri Sosial Nomor 1 Tahun 2018 tentang Program Keluarga Harapan. Untuk mengukur bagaimana implementasi kebijakan Program Keluarga Harapan yang dijalankan di Kelurahan Cigadung Kecamatan Subang Kabupaten Subang. Menurut Daniel Mazmanian dan Sabatier dalam Anggara(1983:257) menyatakan bahwa ada tiga dimensi yang mempengaruhi keberhasilan implementasi kebijakan, yakni: Implementasi kebijakan publik yang dimaksud penelitian ini adalah implementasi dari Peraturan Menteri Sosial Nomor 1 Tahun 2018 tentang Program Keluarga Harapan. Untuk mengukur bagaimana implementasi kebijakan Program Keluarga Harapan yang dijalankan di Kelurahan Cigadung Kecamatan Subang Kabupaten Subang. Menurut Daniel Mazmanian dan Sabatier dalam Anggara(1983:257) menyatakan bahwa ada tiga dimensi yang mempengaruhi keberhasilan implementasi kebijakan, yakni:

\section{b. Karakteristis Masalah ( Mudah atau tidaknya masalah yang dikendalikan)}

Dimensi ini menganalisa mudah atau tidaknya masalah yang digarap dari program PKH. Artinya menganalisa program PKH dari tingkat kemudahan dan kesulitannya dalam implementasinya yang dilakukan di Kelurahan Cigadung. Menurut pedoman Umum PKH Tahun 2013 bahwa sosialisasi dan komunikasi PKH dirancang untuk terjadinya proses komunikasi, aliran, informasi dan pembelajaran pada berbagai pelaksanaan di pusat dan daerah, kalangan media LSM, akademisi dan masyarakat, termasuk peserta $\mathrm{PKH}$, terutama di daerah $\mathrm{PKH}$. Tersosialisasikanya PKH kepada semua pihak, baik yang terkait langsung maupun tidak langsung, merupakan kunci kesuksesan PKH. Untuk itu disusun strategi 
komunikasi dan sosialisasi ini tidak hanya memfokuskan pada aspek implementasi dan keberhasil pelaksana program PKH tersebut, tetapi yang menjadi aspek pengembangan kebijakan, Khususnya dalam membangunan dukungan dan komitmen untuk melembagakan PKH kedalam bentuk Jaminan sosial.

Melihat hasil wawancara diatas dapat disimpulkan bahwa sosialisasi yang dilakukan sudah cukup baik dan dapat dipahami bersama. Dalam Implementasi Kebijakan Program PKH Tingkat dan ruang lingkup perubahan perilaku yang dikehendaki dalam implementasi kebijakan program PKH di sini adalah merubah pola hidup peserta program PKH atau Rumah Tangga Sangat Miskin (RTSM) untuk menjadi lebih baik tingkat kesejahteraanya dalam hal kesehatan dan Pendidikannya. Berikut wawancara dengan bpk Eki selaku pendamping PKH : "Alhamdulillah setelah adanya PKH para peserta PKH jadi terbantu untuk menyekolahkan anaknya. Tetapi kegiatan pendidikan untuk para peserta PKH ada saja anaknya yang tidak bersekolah". Menyimak hasil wawancara Ruang lingkup dalam perubahan perilaku peserta PKH untuk perbaikan kualitas pendidikan. Kondisi ini masih ditemukan anak yang tidak mau sekolah dan bermalas-malasan. Perilaku tersebut disebebkan faktor kurangnya motivasi dari orang tua dan lingkungan, sehingga lingkungan masyarakat khusunya daerah yang berada jauh dari wilayah pusat pemerintahn kelurahan. menyebabkan anak menjadi malas bersekolah. Menyimak hasil wawancara penulis dengan Kasi PKH Dinas Sosial, Kasi Kesejahteraan Sosial Kel. Cigadung, Pendamping dan Masyarakat. Makan penulis berasumsi bahwa Implementasi Kebijakan Program Keluarga Harapan di Kelurahan Cigadung dilihat dari indikator Karakteristik Masalah belum optimal dimana perilaku yang dikehendaki di Kelurahan Cigadung belum optimal, terlihat dari ruang lingkup dalam perubahan perilaku untuk perubahan kualitas pendidikan yang masih ditemukan anak yang malas dan tidak mau bersekolah. Perilaku tersebut disebabkan faktor kurangnya motivasi dari orangtua dan lingkungan.

\section{c. Karakteristik Kebijakan}

Acuan dalam implementasi kebijakan program PKH di Kelurahan Cigadung yaitu mengacu pada aturan pedoman umum PKH tahun 2013. Secara mekanisme dan prosedur $\mathrm{PKH}$ yang harus dilakukan terdiri atas kegiatan sebagai keikutsertaan daerah dalam PKH dilakukan melalui tahapan pertama adalah pemilihan provinsi. Tahapan ini dilakukan atas dasar kesediaan pemerintah provinsi pada saat musrenbang dan keberagaman karakteristik daerah. Tahap kedua adalah pemilihan kabupaten/kota dan kecamatan. Dimana pemilihan kabupaten/kota dan kecamatan dilakukan dengan memperhatikan data BPS berdasarkan kriteria: (1) tingginya angka kemiskinan, (2) angka gizi buruk dan angka transisi dari SD/MI ke SMP/MTs, (3) ketersediaan sarana dan prasarana supply) baik pendidikan maupun kesehatan. Berdasarkan ungkapan diatas pendamping sudah memberikan petunjuk-petunjuk dan kejelasan tentang tahapan-tahapan tujuan dari Program yang dilaksanakan.

Berdasarkan hasil penelitian penuliss diketahui bahwa Kejelasan aturan prosedur dalam pelaksanaan program PKH di Kelurahan Cigadung dalam dimensi Karakteristik Kebijakan sudah berjalan dengan baik seperti diberikan pedomanpedoman mengenai syarat dan ketentuan menjadi peserta PKH. Dalam kejelasan 
dan konsistensi tujuan ini adalah bagaimana peraturan program $\mathrm{PKH}$ memberikan petunjuk-petunjuk yang cermat. Kemudian, program disusun secara jelas skala prioritasnya, untuk dilaksanakan oleh para pejabat pelaksana $\mathrm{PKH}$ dan pihak lainnya dalam pelaksanaan Program PKH di Kelurahan Cigadung. Kesimpulan yang dirangkum dari gambaran perubahan yang dirasakan oleh KPM atau Peserta Program PKH setelah mereka mendapatkan program tersebut terlihat sangat dirasakan manfaatnya, baik dari akses untuk mendapatkan pelayanan kesehatan maupun pelayanan pendidikan. Meski demikian, untuk jangka panjang Program $\mathrm{PKH}$, yang diharapkan akan terjadi perubahan pola pikir dan perilaku serta kesinambungan terhadap perbaikan kesehatan ibu hamil, balita serta tingkat pendidikan anak-anak RTSM/KPM, belum bisa terlihat. Sehingga Program PKH yang bisa memutus rantai kemiskinan yang ada di Kelurahan Cigadung belum bisa dilihat dengan nyata. Penulis berasumsi bahwa implementasi kebijakan Program Keluarga Harapan di Kelurahan Cigadung Kecamatan Subang Kabupaten Subang dilihat dari indikator Karakteristik Kebijakan belum optimal hal ini dilihat dari ketepatan alokasi sumber dana yang belum optimal saat proses pendistribusian dana PKH. Dan pelanggaran aturan program PKH untuk penyalahgunaan dana digunakan untuk kebutuhan diluar ketentuan, seperti untuk memenuhi kebutuhan sehari-hari orang tua dan untuk memperbaiki tempat tinggal yang sudah rusak.

\section{d. Lingkungan Kebijakan ( di Luar Kebijakan)}

Yang Mempengaruhi Proses Implementasi dimensi yang ketiga ini seperti mengacu pada konsepnya Daniel Mazmanian dan Paul Sabatier (dalam Agustino, 2006:144), dalam hal ini dimensi di luar kebijakan yang mempengaruhi implementasi kebijakan pada program PKH di Kelurahan Cigadun.Kondisi SosialEkonomi Dan Teknologi Penilaian dari indikator ini adalah analisa yang dilihat perbedaan waktu dan perbedaan wilayah hukum pemerintah dalam kondisi sosial, ekonomi dan teknologi yang dapat mempengaruhi pencapaian tujuan program PKH di Kelurahan Cigadung. Seperti yang dikatakan pendamping ibu Nenden "Penduduk di kelurahan cigadung rata-rata bermatapencaharian bertani tanam pangan, berkebun, serabutan tidak punya pekerjaan yang tetap. Kemudian tekonlogi, seperti sarana komunikasi dan teknologi informasi khususnya yang mempunyai handphone di kelurahan cigadung masih banyak yang tidak memiliki handphone." (20 September 2019). Berikut adalah hasil wawancara dengan Kasi $\mathrm{PKH}$ : "Kondisi ekonomi yang menjadi kelompok sasaran yaitu yang berpendapatan rendah. Ketika sosial ekonomi yang ada masyrakat buruk maka akan berpengaruh terhadap kebijakan, jadi kebijakan pemerintah harus menentukan dan melakukan apa yang harus diberikan ke Kelurahan tersebut agar Program Keluarga Harapan terlealisasi dengan baik." Dari kutipan wawancara di atas menyatakan bahwa keadaan ekonomi yang ada di masyarakat yang menjadi kelompok sasaran masih rata-rata masih berpendapatan rendah, sehingga keadaan ekonomi masyarakat akan mempengaruhi implementasi kebijakan program keluarga harapan hal ini dilihat dari ketika mereka berpenghasilan rendah maka tidak akan memperhatikan kualitas hidupnya. Indikator ini menilai sumbersumber yang dimiliki warga dan sikap-sikap masyarakat yang kondusif atau tidak dalam mendukung program PKH atau semacam kearifan lokal yang dimiliki oleh warga yang dapat mempengaruhi keberhasilan atau ketidakberhasilan 
implementasi kebijakan program PKH di Kelurahan Cigadung. Berikut wawancara dengan Bapak Eki selaku Pendamping PKH di Kelurahan Cigadung : "Untuk masyarakat dan pejabat RT/RW alhamdulillah mereka ikut mengawasi keberlangsungan Program Keluarga Harapan. Mereka juga saling memotivasi dan bahkan ada yang membantu untuk mengajarkan KPM berwirausaha, agar mereka dapat membuka usaha walaupun kecil." (tanggal 6 September 2019)

Hasil wawancara diatas menunjukan kesepakatan dan kemampuan dalam mengImplementasikan PKH cukup mampu mewujudkan kehendak dan harapan rakyat dan strategi yang dilakukan dapat mencapai keberhasilan (berjalan dengan lancar). Dengan begitu implementasi kebijakan Program Keluarga Harapan di Kelurahan Cigadung berjalan lancar, jika tidak ada kesepatan dan kemampuan Kepemimpinan para pejabar pelaksana mereka akan seenaknya dan mempergunakan dana tidak sesuai dengan ketentuan. Hal ini sebagai indikasi pentingnya keberhasilan kinerja implementasi program $\mathrm{PKH}$ di Kelurahan Cigadung. Dari proses implementasi kebijakan yang telah berjalan dalam realisasi program PKH di Kelurahan Cigadung, para petugas atau pendamping sudah melakukan koordinasi untuk melibatkan pihah lain, atau lembaga-lembaga terkait seperti pejabat RT/RW dan lembaga-lembaga pendidikan serta kesehatan. Sehingga keberhasilan program PKH di Kelurahan Cigadung sudah terealisasi dengan baik mencapai tujuan yang digariskan yaitu membantu mengurangi kemiskinan dengan cara meningkatkan kualitas sumber daya manusia pada kelompok masyarakat sangat miskin.

Menyimak hasil wawancara penulis dengan Dinas Sosial, Kasi Kesejahteraan Sosial kel.cigadung, pendamping dan masyarakat. Maka penulis berasumsi bahwa Implementasi Kebijakan Program Keluarga Harapan di Kelurahan Cigadung Kecamatan Subang Kabupaten Subang dilihat dari indikator kondisi sosialekonomi dan teknologi belum optimal hal ini dilihat dari:

1) Kondisi ekonomi masyarakat yang menjadi kelompok sasaran ini rata-rata berpendapatan rendah. Dan salah satu kesulitan pendamping adalah alat komunikasi seperti handphone masih menjadi alat mewah dan sulit dioperasikan oleh peserta PKH.

2) Kondisi ekonomi berpengaruh karena masyarakat rata-rata berpendapatan rendah maka mereka tidak memperhatikan kualitas hidupnya.

3) Berdasarkan hasil penelitian dan pembahasan diatas, maka peneliti dapat memberikan intisari atau rangkuman dari dimensi dan indikator-indikator yang telah dibahas diatas. Adapun intisari yang peneliti temukan :

Dimensi Karakteristik Masalah ( mudah atau tidaknya masalah yang digarap dari program $\mathrm{PKH}$, artinya peneliti menganalisa program $\mathrm{PKH}$ dari tingkat kemudahan dan kesulitannya dalam implementasi kebijakannya, yang mencakup:

a. Kesukaran teknis atau mudahnya persyaratan teknis, yang di dalamnya termasuk kemampuan untuk mengembangkan indikator-indikator pengukur prestasi kerjadalam mencapai tujuan PKH

b. Keberagaman perilaku yang diatur dalam program $\mathrm{PKH}$, baik prilaku penerima PKH maupun pejabat pelaksana PKH

c. Tingkat dan ruang lingkup perubahan perilaku yang dikehendaki, yaitu merubah pola hidup peserta program PKH atau Rumah Tangga Sangat Miskin (RTSM) untuk menjadi lebih baik tingkat kesejahteraannya. 
1. Dimensi kemampuan kebijakan $\mathrm{PKH}$ menstruktur proses implementasinya secara cepat, terdiri atas:

a) Kejelasan dan konsistensi tujuan, artinya menganalisa program peraturan PKH memberikan petunjuk- petunjuk yang cermat dan disusun secara jelas skala prioritasnya untuk dilaksanakan oleh para pejabat pelaksana PKH dan aktor lainnya dalam pelaksanaan program PKH.

b) Dipergunakannya teori kausal, artinya konsep ini menganalisa perubahan kualitas kehidupan masyarakat miskin atau RTSM yang menjadi sasaran tujuan PKH, ketika PKH tersebut terealisasi.

c) Ketepatan alokasi sumberdana, artinya analisa yang digunakan melihat distribusi sumber dana yang dipergunakan RTSM dan paratim pendamping untuk sampai kepenerima.

d) Keterpaduan hierarki antara lembaga pelaksana, artinya analisa yang dilakukan mengetahui kemampuan untuk menyatu padukan atau koordinasi dari dinas, badan, dan lembaga pelaksana dari program PKH.

e) Aturan pelaksana dari lembaga pembuat pelaksana, artinya analisa yang dilihat mengenai kejelasan dan konsistensi tujuan dan kepatuhan kelompok sasaran pada aturan yang telah ditetapkan dari lembagalembaga pelaksana dalam implementasi program $\mathrm{PKH}$.

f) Perekrutan pejabat pelaksana, artinya analisanya melihat fenomena para pejabat pelaksana PKH menjalankan kesepakatan atau kepatuhan pada komitmen yang telah disyaratkan demi tercapainya tujuan PKH.

g) Keterbukaan terhadap pihak luar, artinya menganalisa keterlibatan pihak luar dari lembaga di luar pelaksanaprogram $\mathrm{PKH}$ ikut terlibat dalam mendukung tujuan program PKH.

2. Dimensi diluar kebijakan yang mempengaruhi proses implementasi

a) Kondisi sosial-ekonomi dan teknologi, artinya penilaian analisa yang dilihat perbedaan waktu dan perbedaan wilayah-wilayah hukum pemerintah dalam kondisi sosial, ekonomi dan teknologi yang dapat mempengaruhi pencapaian tujuan program $\mathrm{PKH}$.

b) Dukungan publik, artinya analisa yang dilihat berupa dukungan dari warga atau masyarakat lainterhadaptujuan program PKH

c) Sikap dan sumber-sumber yang dimiliki masyarakat, hal ini menilai dan menganalisa sumber-sumber yang dimiliki warga dan sikap-sikap masyarakat yang kondusif atau tidak dalam dukungan program $\mathrm{PKH}$ atau semacam kearifan lokal yang dimiliki oleh warga yang dapat mempengaruhi keberhasilan atau ketidakberhasilan implementasi kebijakan program PKH.

d) Kesepakatan dan kemampuan kepemimpinan para pejabat pelaksana, dalam hal ini analisa yang dilihat berupa kesepakatan para pejabat pelaksana $\mathrm{PKH}$ menjalankan fungsi dari kemampuan dari aturan kebijakan PKH dan kemampuan berinteraksi antar lembaga untuk mensukseskan implementasi kebijakan program $\mathrm{PKH}$, sebagai indikasi penting keberhasilan kinerja implementasi program PKH di Kelurahan Cigadung. 


\section{Kesimpulan}

Berdasarkan hasil penelitian yang dilakukan penulis mengenai Implementasi Kebijakan Program Keluarga Harapan di Kelurahan Cigadung Kecamatan Subang Kabupaten Subang masih banyak memiliki kendala yang terjadi. Sesuai kesimpulan ketiga dimensi menurut Daniel Mazmanian dan Sabatier diatas dapat dilihat bahwa Implementasi Kebijakan Program Keluarga Harapan masih mengalami masalah dari beberapa dimensi implementasi. Berdasarkan hasil penelitian penulis diatas mengenai Implementasi Kebijakan Program Keluarga Harapan di Kelurahan Cigadung Kecamatan Subang Kabupaten Subang belum optimal, hal ini dilihat dari dimensi:

1) Karakteristik Masalah

2) Tingkat dan Ruang Lingkup perilaku yang dikehendaki di Kelurahan Cigadung masih rendah, terlihat dari ruang lingkup dalam perubahan perilaku untuk perubahan kualitas pendidikan yang masih ditemukan anak yang malas dan tidak mau bersekolah. Perilaku tersebut disebabkan faktor kurangnya motivasi dari orangtua dan lingkungan. Dengan demikian dimensi Karakteristik Masalah pelaksana tidak optimal.

3) Karakteristik Kebijakan

4) Ketepatan alokasi sumber dana yang belum optimal saat proses pendistribusian dana PKH. Dan pelanggaran aturan program PKH untuk penyalahgunaan Dana PKH digunakan untuk kebutuhan diluar ketentuan, seperti untuk memenuhi kebutuhan sehari-hari orang tua dan untuk memperbaiki tempat tinggal yang sudah rusak. Dengan demikian dimensi Karakteristik Kebijakan tidak optimal.

5) Lingkungan Kebijakan

6) Kondisi ekonomi masyarakat yang menjadi kelompok sasaran ini rata-rata berpendapatan rendah sehingga berpengaruh terhadap implementasi kebijakan. Masyarakat rata-rata berpendapatan rendah maka mereka tidak memperhatikan kualitas hidupnya. Dengan demikian kondisi sosial-ekonomi dan teknologi tidak optimal.

\section{Referensi}

Anggara, Sahya, 2014. Kebijakan Publik, cetakan pertama, penerbit Pustaka Setia Bandung. Agustino, Leo. 2006. Dasar-dasar Kebijakan Publik. Bandung: CV Alfabeta.

Budi Winarno,MA. phD, 2012. Kebijakan Publik (Teori, Proses, dan Studi Kasus) Yogyakarta.

Harbani, Pasolong, 2016. Metode Penelitian Administrasi Publik, Alfabeta Bandung

Haughton, Jonathan dan Shahidur R.Khandker, Pedoman Tentang Kemiskinan Dan Ketimpangan, Jakarta: Salemba Empat,2012

Kementrian RI, Program Keluarga Harapan, 2016 
Khosman, Ali, dkk, Indikator Kemiskinan dan Klarifikasi Orang Miskin, Jakarta Yayasan Pustaka Obor Indonesia. 2015

Peraturan Bupati Subang Nomor: 63 Tahun 2016 Tentang Tugas Pokok, Fungsi Dan Tata Kerja Dinas Sosial Kabupaten Subang

Rusli, Budiman, 2013. Kebijakan Publik, (Membangun Pelayanan Publik yang Responsif), cetakan pertama, penerbit Hakim Publishing Bandung.

Satipsi, Evi, 2017. Kapita Selekta Perencanaan, Implementasi, Evaluasi Program, Jilid 1, cetakan pertama, penerbit Deepublish Yogyakarta.

Setiawan, Guntur, 2004. Implementasi Dalam Birokrasi Pembangunan. Balai Pustaka,Jakarta.

Sugiyono, 2017. Metode Penelitian Kuantitatif, Kualitatif. Cetakan ke 25, penerbit Alfabeta Bandung.

Sugiyono, 2008. Metode Penelitian Kuantitatif Dan Kualitatif, Bandung:Alfabeta.

Undang-Undang Nomor 13 Tahun 1998 tentang Kesejahteraan Lanjut Usia

Undang-Undang Nomor 11 Tahun 2009 tentang Kesejahteraan Sosial

Undang-Undang Nomor 13 Tahun 2011 tentang Penanganan Fakir Miskin

Undang-Undang Nomor 8 Tahun 2016 tentang Penyandang Disabilitas

Permensos No.1 Tahun 2018 tentang Pelaksanaan Program Keluarga Harapan

Peraturan Presiden No.63 Tahun 2017 tentang Penyaluran Bantuan Sosial Non Tun

Widodo, Joko, Analisis Kebijakan Publik: Konsep dan Aplikasi Analisis Proses Kebijakan Publik, Sidoarjo:Bayumedia Publishing,2006. 